\title{
Hindistan'ın Coronavirus Salgını ile Mücadele Yolu
}

\section{Fighting Coronavirus Pandemic the Indian Way}

\author{
${ }^{1}$ Gurmeet SINGH SARLA \\ ${ }^{1}$ Senior Registrar, 159 General Hospital, Pin 900345, India \\ Gurmeet Singh Sarla: https://orcid.org/0000-0002-9288-9999
}

\begin{abstract}
ÖZ
COVID-19, asemptomatik olmayandan solunum yetmezliği tanısı konan klinik durumlara kadar çeşitli derecelerle kendini gösterebilir. Hastalığın tedavisi çoğunlukla oksijen takviyesi, invaziv olmayan ventilasyon ve ağır durumlarda ise mekanik ventilasyon uygulanması şeklindedir. Şu anda hastalığa karş1 etkili bir antiviral ilaç veya aşı mevcut değildir. Enfeksiyonun yayılmasıyla mücadele için izolasyon, sosyal uzaklaşma, iç mekanda kalma, kitle buluşmalarından stratejik olarak mesafeyi koruma Hindistan'ın takip ettiği ve etkili sonuç almak istediği temel, pratik ve uygun yöntemlerdir. Burada maske kullanımı hakkında büyük bir tartışma bulunmaktadır ve bu konu üzerinde durulmaktadır. Bu derleme çalışmada el temizliği, elleri yıkamak için sabun ve su kullanımı, el dezenfektanı kullanımı, iç mekanda kalmanın psikolojik etkileri gibi farmakolojik olmayan önlemler ve bu enfeksiyonun tedavisi için araştırılan seçenekleri Hint perspektifinden tartışılmıştır.
\end{abstract}

Anahtar Kelimeler: Koronavirüs, el dezenfektanı, el hijyeni, sosyal mesafe, yüz maskesi

\begin{abstract}
COVID-19 may manifest with a diverse clinical spectrum from being asymptomatic to clinical conditions characterized by respiratory failure. The treatment of the illness is for the most part supportive as oxygen supplementation, non-invasive ventilation and in extreme cases, mechanical ventilation. No effective antiviral drugs or vaccine against the disease is available at the moment. Isolation, social distancing, remaining indoors, maintaining a strategic distance from mass get-togethers are the basic, practical, affordable methods for battling the spread of the infection which India is following and would like to have a great result. There is a great deal of debate about the use of mask and the issue has been deliberated upon. Non pharmacological measures like hand cleanliness, utilization of soap and water to wash hands, utilization of hand sanitizer, the psychological impacts of the lock-down and the options being explored for treatment of this infection have been discussed in this review study from an Indian perspective. Keywords: Coronavirus, face mask, hand hygiene, hand sanitizer, social distancing
\end{abstract}

Sorumlu Yazar / Corresponding Author:

Gurmeet Singh Sarla

Senior Registrar, 159 General Hospital, Pin 900345, India

Phone : +919882562223

E Mail: rijak1@gmail.com
Yayın Bilgisi / Article Info:

Gönderi Tarihi/ Received: 20/04/2020

Kabul Tarihi/ Accepted: 04/06/2020

Online Yayın Tarihi/ Published: 30/06/2020

Atıf/ Cited: Singh Sarla G. Fighting coronavirus pandemic the Indian way. Online Türk Sağllk Bilimleri Dergisi 2020;5(2):394-399. doi: 10.26453/otjhs.723829

\section{INTRODUCTION}

In late December 2019, a group of unexplained pneumonia cases have been accounted for in Wuhan, China. As they couldn't distinguish the causative factor, these first cases were named "pneumonia of unknown etiology" which is currently credited to a novel infection having a place with the coronavirus (CoV) family."COVID-19" is the acronym of "coronavirus disease 2019" and the causative virus is by all accounts infectious and has immediately spread comprehensively. ${ }^{1}$ The clinical range of
COVID-19 differs from being asymptomatic to clinical conditions described by respiratory failure.

\section{DISCUSSION AND CONCLUSION}

The virus originated in bats and was transmitted to humans through yet unknown intermediary animals in Wuhan, Hubei province, China in December $2019 .^{2}$ Because the first cases of the CoVID-19 disease were linked to direct exposure to the Huanan Seafood Wholesale Market of Wuhan, the animal-to -human transmission was presumed as the main mechanism. As subsequent cases were not associa- 
ted with this exposure mechanism, it was concluded that the virus could also be transmitted from humanto-human, and symptomatic people are the most frequent source of COVID-19 spread.

Transmission: The infection is transmitted by inhalation or contact with infected droplets and the incubation period ranges from 2 to 14 days $^{2}$ and the virus replicates locally in cells of the ciliated epithelium of the respiratory tract, causing cell damage and inflammation. Based on data from the first cases in Wuhan and investigations conducted by the China CDC and local CDCs, the incubation time could be generally within 3 to 7 days and up to 2 weeks as the longest time from infection to symptoms was 12.5 days. $^{3}$ This data also showed that this novel epidemic doubled about every seven days, whereas the basic reproduction number ( $\mathrm{R} 0$ - $\mathrm{R}$ naught) is 2.2. In other words, on an average, each patient transmits the infection to an additional 2.2 individuals. Of note, estimations of the R0 of the SARS-CoV epidemic in 2002-2003 were approximately $3 .^{4}$

Carriers: Studies have suggested that $2 \%$ of the population are healthy carriers of $\mathrm{acV}$ and that these viruses are responsible for about $5 \%$ to $10 \%$ of acute respiratory infections. ${ }^{5}$ Asymptomatic carriers intensifies the difficulty of prevention and management of the infection. ${ }^{6}$ Comprehensive rigorous epidemiological investigation and combination of multiple detection methods were of great value for the detection of hidden asymptomatic carriers. ${ }^{6}$

Presentation: The clinical spectrum of COVID-19 varies from being asymptomatic to clinical conditions characterized by respiratory failure that necessitates mechanical ventilation and support in an intensive care unit, to sepsis, septic shock, and multiple organ dysfunction syndrome (MODS). ${ }^{1}$ Common clinical manifestations included fever, cough, nasal congestion, chest tightness/pain, fatigue, bodyache and sore throat in patients with mild or uncomplicated illness. Some patients may have moderate illness and may have respiratory symptoms such as cough and shortness of breath. Severe illness may present as fever associated with severe dyspnoea, respiratory distress, tachypnoea, and hypoxia. ${ }^{1}$

Management: The principal treatment modality of patients with severe illness is oxygen treatment. The subsequent stage if the patient doesn't respond well to oxygen supplementation is Non-invasive ventilation (NIV) trailed by intubation and invasive mechanical ventilation. There is no particular antiviral treatment prescribed for COVID-19 nor is any vaccine accessible. The treatment is symptomatic and oxygen treatment forms the mainstay of supportive treatment for patients with serious disease. Mechanical ventilation might be important in instances of respiratory failure unmanageable to oxygen treatment though hemodynamic support is basic for overseeing management of septic shock. ${ }^{1}$

Screening: The World Health Organisation (WHO) has criticised countries that have not prioritised testing. Tedros Ghebreyesus, the chief executive of WHO, said, "You cannot fight a fire blindfolded. Our key message is test, test, test". India has limited testing capabilities due to paucity of testing kits hence patients with severe respiratory illness admitted in intensive care units with suspected COVID19, patients with a travel history from affected areas: China, Italy, Iran, Japan, and South Korea and people who had close contact with a patient with laboratoryconfirmed COVID-19 within 14 days of onset of symptoms are being tested for the infection. WHO is stressing on testing and screening everybody whilst Indian Council of Medical Research (ICMR) wants the Indian government to concentrate on isolation and social distancing and test only the symptomatic and individuals with a travel history or contact with a positive patient. India ranks much lower as far as screening is concerned. If people are not screened, they won't be diagnosed and if they are not diagnosed to have the infection, they would not be isolated, quarantined and treated. ${ }^{8}$ The Indian government is using screening judiciously and effectively due to the high cost and low availability of the screening kits and trying to limit the infection to as few individuals as possible before this becomes like a wildfire difficult to control due to limited medical resources and health infrastructure. ${ }^{9}$

\section{PREVENTION OF THE SPREAD OF INFEC- TION}

Quarantine: Quarantine limits the movement of individuals who were exposed to an infectious ailment to check whether they become sick. These individuals may have been exposed to a disease and don't know it, or they may have the infection however are not symptomatic.9 Quarantine is characterized as confinement forced upon ships, people, creatures or plants on landing in a port, for the most part of 40 days, when associated with conveying an irresistible or infectious illness. ${ }^{9}$ It is being rehearsed since the hours of bubonic plague in the fourteenth century when boats showing up in Venice from zones hit with bubonic plague were required to grapple away from port for 40 days before docking and is being 
suggested in corona infection pandemic in the form of either home quarantine or institutional quarantine.

Isolation: Isolation separates sick people with a contagious disease like leprosy, chicken pox and conjunctivitis from people who are not sick. Quarantine and isolation constitute two commonly used epidemic control measures. Although isolation is probably always a desirable public health measure, quarantine is more controversial and mass quarantine can inflict significant social, psychological, and economic costs without resulting in the detection of many infected individuals. ${ }^{8}$

Social distancing: Social distancing is a nonpharmaceutical infection prevention and control intercession actualized to maintain a strategic distance from/decline contact between the individuals who are infected with a malady causing pathogen and the individuals who are not, to stop or hinder the rate and degree of infection transmission in a network. Forestalling mass gatherings and crowds help in social distancing and keeping up a distance of 1 meter (3 feet) is suggested. For influenza as infectious as 1957 -58 Asian flu ( $\approx 50 \%$ infected), closing schools and keeping children and teenagers at home reduced the attack rate by $>90 \%{ }^{9}$

Lockdown: A lockdown is a crisis convention initiated by the state authorities that normally keep individuals from leaving a territory. A full lockdown for the most part implies that individuals must remain where they are and may not move. A significantly decreased growth rate and increased doubling time of cases has been observed with implementation of lockdown measures. ${ }^{10}$ The lockdown is like a dam holding waters to prevent floods and the advisories of the government agencies should be strictly followed to prevent crumbling under the case loads.

\section{INDIA LOCKED DOWN}

On January 30 2020, the first COVID diagnosis was made in India and to control community transmission, the Indian government declared a 21 day nationwide lockdown starting on 24 March 2020 which was further extended to a total of 40 days. ${ }^{11}$ India has the second largest population after China but India's population density far exceeds China's $\left(455 / \mathrm{km}^{2}\right.$ in India vs $148 / \mathrm{km}^{2}$ in China). ${ }^{12}$ A pandemic is a game of numbers and about approximately one fourth of the population of the world resides in India. A vastly and densely populated country is trying to control the virus not inside the hospital but outside it, using not clinical medicine but by using preventive and social medicine and the fundamentals of epidemiology.
Singh and Adhikari ${ }^{13}$ stressed the importance of social distancing as the only effective tool against COVID and have recommended two models for an effective lockdown in the form of a complete lockdown of 49 days or a phased lockdown of 21, 28 and 18 days with intervening 5 days period of relaxation.

Masks: Masks are available as cloth masks, surgical masks, N95 masks and it is recommended that the general population, sick people with respiratory symptoms and people who are working in health care facilities who are not in direct contact with patients may use a home-made cloth mask. Homemade masks, and to a lesser degree surgical masks, are probably not going to present a lot of assurance against transmission of small droplets, yet as the reproduction number of influenza may not be high, a little decrease in transmissibility of the infection might be adequate for diminishing the proliferation number to a value less than 1 and in this way dousing the epidemic. ${ }^{14}$ People who are involved in patient care should wear surgical masks and N95 masks may be worn by medicals like Anaesthetists and Internal Medicine Specialists who are exposed to respiratory secretions of infected people during endotracheal intubation and other invasive procedures.

Hand washing: Hand hygiene has been considered the leading measure to prevent spread of infections. ${ }^{15}$ A study reveals that instant hand wiping using a wet towel soaked in water containing $1.00 \%$ soap powder, $0.05 \%$ active chlorine, or $0.25 \%$ active chlorine from sodium hypochlorite removed $98.36 \%, 96.62 \%$, and $99.98 \%$ of the virus from hands, respectively. ${ }^{16}$

Hand sanitizer: Alcohol-based hand sanitizers with a concentration of $60 \%$ to $95 \%$ ethanol or isopropanol are recommended as a component of hand hygiene. ${ }^{17}$

Arogya Setu Application: Aarogya Setu, a mobile application developed by the ministry of electronics and IT in India to help citizens identify their risk of contracting Covid-19. ${ }^{18}$ It is designed to keep a user informed in case $\mathrm{s} / \mathrm{he}$ has crossed paths with someone who has tested positive and the tracking is done through bluetooth \& location-generated social graph, which can show your interaction with anyone who has tested positive.

Immunity: Not all individuals exposed to coronavirus are infected and not all infected patients develop severe respiratory illness. The infection can be divided into stage I, an asymptomatic incubation period with or without detectable virus; stage II, nonsevere symptomatic period with the presence of virus; stage III, severe respiratory symptomatic stage with high viral load. ${ }^{18} 15 \%$ of the confirmed cases 
progress to severe phase, although there is a higher chance for patients over 65 to progress into the severe phase probably due to decrease in the immune status of the elderly. ${ }^{19}$ Italy has been found to have a large number of elderly population as per the demography and has been cited as one of the reasons of it being so badly hit by the infection. COVID also has a poorer prognosis in diabetics probably due to their poor immune system.

Chloroquine and Hydroxychloroquine: Despite there being limited evidence to suggest a role of chloroquine and hydroxychloroquine in prophylaxis and treatment of COVID, due to the absence of any other valid treatment option and the low cost of chloroquine and hydroxychloroquine; these two drugs have generated interest world over to be tried as a prophylactic agent for health care workers exposed to COVID positive patients. ${ }^{20}$ Chloroquine phosphate in the dose of $500 \mathrm{mg}$ twice daily for 5-10 days and hydroxychloroquine as a loading dose of $400 \mathrm{mg}$ on day one followed by $200 \mathrm{mg}$ twice daily for 5-10 days under supervision of an Internist is being tried with unproven results. ${ }^{20}$

Infodemic: When disease can travel so quickly, information has to move even faster. Media, in it's attempt to be quick has raised alarmist rhetoric of the stories and has fuelled panic and anxiety about the disease in the general public. The language being used in the media to describe the outbreak is undoubtedly contributing to the mass hysteria about the disease and have converted the pandemic into an infodemic with abundance of unnecessary and irrelevant information. ${ }^{1}$

Mental effects: COVID is extraordinary for it's vulnerability of span, course, prognosis and result and the lock-down has set in a sense of instability, unusualness, imprisonment, vagrancy and desperation. We have to promise individuals that lock-down isn't an impingement on their fundamental human right to move uninhibitedly in their own territory however the least complex, most savvy and a compelling treatment against the infection. ${ }^{9}$ Individuals ought to be made mindful that isolation isn't detainment yet restriction at explicit spots to forestall the spread of infection and they ought to show restraint, remain at home and avoid gatherings. 9

Anosmia and Ageusia: Coronavirus infection is associated with dysfunction of olfaction and taste perception, which may be among the earliest symptoms in an unknown proportion of confirmed cases. Disruption of ciliary nasal epithelium has been postulated as a possible mechanism of olfactory dysfunc- tion. $^{21}$

Treatment options being explored: Remdesivir a nucleotide analogue prodrug found to inhibit the replication of SARS-CoV and MERS-CoV in tissue cultures. Brown AJ found that Remdesivir potently blocks SARS-CoV-2 infection at low micromolar concentrations and has a high selectivity index. ${ }^{22}$ Holshue et al. also reported promising results of Remdesivir in the treatment of COVID-19. ${ }^{23}$ Lopinavir is a human immunodeficiency virus 1 (HIV-1) protease inhibitor used in combination with Ritonavir to increase the half-life of Lopinavir by inhibiting cytochrome P450. Combination of these anti HIV drugs have shown anti-SARS-CoV activity in vitro and in clinical studies. ${ }^{24}$ Favipiravir is a RNAdependent RNA polymerase inhibitor capable of blocking the replication of RNA viruses. ${ }^{25}$ It converts into an active form (Favipiravir-RTP) in cells and is recognized as a substrate by viral RNA polymerase, thus inhibiting RNA polymerase activity. ${ }^{26}$ Chloroquine and Hydroxychloroquine have been found to be effective against SARS-CoV-2 and are under investigation for the treatment of COVID-19. Studies found that treating patients diagnosed with pneumonia due to novel coronavirus with Chloroquine might improve the success rate of treatment, shorten hospital stay and improve patient outcome. ${ }^{27}$ It has been reported that plasma therapy in the recovery phase can reduce the mortality of patients with severe influenza A and SARS-CoV infection. ${ }^{28}$ Evidence shows that convalescent plasma from the recovered patient can be used as a treatment without the occurrence of severe adverse events. ${ }^{29}$

In conclusion; Coronavirus infection disease has profoundly affected the lives of each and everybody living in this world. Quarantine, Isolation, social distancing, remaining indoor, maintaining a strategic distance from mass get-togethers are basic, handy, prudent methods for battling the spread of the infection which India is following and would like to have an ideal result.

Cloth masks made at home from clean cotton fabric which ought to be changed daily might be utilized by general population and the non-technical staff working in a health care facility who are not directly involved in patient care. Surgical masks might be utilized by the medical and paramedical staff engaged in patient care and N-95 mask might be used by the Anaesthesiologists and the Respiratory Physicians who perform interventional procedures and are in close contact with the infected patients.

Hand washing with soap and water is the most sig- 
nificant thing to forestall spread of disease. Hand sanitizer might be utilized while voyaging where soap and water are not accessible.

Coronavirus infection is associated with dysfunction of olfaction and taste perception. COVID is extraordinary for it's vulnerability of span, course, prognosis and result and the lock-down has set in a sense of instability, unusualness, imprisonment, vagrancy and desperation. Individuals ought to be made mindful that isolation isn't detainment yet restriction at explicit spots to forestall the spread of infection and they ought to show restraint, remain at home and avoid gatherings.

Ethics Committee Approval: Our study was a review article. No ethics committee permission is required.

Conflict of Interest: No conflict of interest was declared by the author.

Author Contributions: Concept, Supervision, Materials, Data Collection and/or Processing, Analysis and/ or Interpretation and Writing -GSS.

Peer-review: It is an article invited by the editor.

\section{REFERENCES}

1. Singh Sarla G. COVID 19: Myths and Facts. Journal of Research \& Review: Management of Emergency and Trauma Nursing. 2020;2(2):5-8. doi: 10.5281/zenodo. 3742655

2. Singhal T. A Review of Coronavirus Disease2019 (COVID-19). Indian J Pediatr. 2020;87 (4):281-286. doi: 10.1007/s12098-020-03263-6

3. Li Q, Guan X, Wu P, et al. Early Transmission Dynamics in Wuhan, China, of Novel Coronavirus-Infected Pneumonia. N. Engl. J. Med. 2020;382(13):1199-1207.

4. Bauch CT, Lloyd-Smith JO, Coffee MP, Galvani AP. Dynamically modeling SARS and other newly emerging respiratory illnesses: past, present, and future. Epidemiology. 2005;16(6):791801.

5. Chen Y, Liu Q, Guo D. Emerging coronaviruses: Genome structure, replication, and pathogenesis. J. Med. Virol. 2020;92(4):418-423.

6. Lu S, Lin J, Zhang Z, et al. Alert for nonrespiratory symptoms of Coronavirus Disease 2019 (COVID-19) patients in epidemic period: A case report of familial cluster with three asymptomatic COVID-19 patients. J Med Virol. 2020. doi: https://doi.org/10.1002/jmv.25776

7. WHO; 2020. WHO Director-General's opening remarks at the media briefing on COVID19.Available: https://www.who.int/dg/speeches/ detail/who-director-general-s-opening-remarks-at -the-media-briefing-on-covid-19-16-mar-2020 Accessed on 25 Mar, 2020.

8. Carter LJ, Garner LV, Smoot JW, et al. Assay Techniques and Test Development for COVID-19 Diagnosis. ACS Cent Sci. 2020;6(5):591-605. doi:10.1021/acscentsci.0c00501

9. Singh Sarla G. Coronavirus Pandemic: An Indian Perspective. Journal of Research \& Review: Management of Cardiovascular and Orthopedic Complications. 2020;2(2):1-4. doi: 10.5281/ zenodo. 3760546

10. Day T, Park A, Madras N, Gumel A, Wu J. When is quarantine a useful control strategy for emerging infectious diseases? Am J Epidemiol. 2006;163(5):479-85.

11.https://www.mohfw.gov.in Accessed on 25 Mar, 2020.

12. Lamba I. Why India needs to extend the nationwide. Am J Emerg Med. 2020;S0735-6757(20) 30254-0. doi:10.1016/j.ajem.2020.04.026.

13. Singh R, Adhikari R. Age-structured impact of social distancing on the COVID-19 epidemic in India. arXiv. 2003:12055. 2020.

14. Glass RJ, Glass LM, Beyeler WE, Min HJ. Targeted social distancing design for pandemic influenza. Emerg Infect Dis. 2006;12(11):1671- 1681. doi:10.3201/eid1211.060255.

15. Borghesi A, Stronati M. Strategies for the prevention of hospital-acquired infections in the neonatal intensive care unit. J Hosp Infect. 2008;68 (4):293-300.

16. Ma QX, Shan H, Zhang HL, et al. Potential utilities of mask-wearing and instant hand hygiene for fighting SARS-CoV-2. J Med Virol. 2020. doi: 10.1002/jmv.25805

17. Boyce JM, Pittet D. Healthcare Infection Control Practices Advisory Committee, HICPAC/SHEA/ APIC/IDSA Hand Hygiene Task Force Guideline for hand hygiene in health-care settings. Recommendations of the Healthcare Infection Control Practices Advisory Committee and the HICPAC/ SHEA/APIC/IDSA Hand Hygiene Task Force. MMWR Recomm Rep. 2002;51(RR-16):145.

18. Garg S, Bhatnagar N, Gangadharan N. A Case for Participatory Disease Surveillance of the COVID19 Pandemic in India. JMIR Public Health Surveill. 2020;6(2). doi: 10.2196/18795

19. Shi Y, Wang Y, Shao C, et al. COVID-19 infection: the perspectives on immune responses. Cell Death Differ. 2020;27(5):1451-1454. 
doi:10.1038/s41418-020-0530-3

20. Singh AK, Singh A, Shaikh A, Singh R, Misra A. Chloroquine and hydroxychloroquine in the treatment of COVID-19 with or without diabetes: A systematic search and a narrative review with a special reference to India and other developing countries. Diabetes Metab Syndr. 2020;14(3):241 -246. doi: 10.1016/j.dsx.2020.03.011

21. Chilvers M.A, McKean M, Rutman A, et al. The effects of coronavirus on human nasal ciliated respiratory epithelium. Eur. Respir. J. 2001;18:965-970.

22. Brown AJ, Won JJ, Graham RL et al. The Broad Spectrum Antiviral remdesivir inhibits Human endemic and zoonotic deltacoronaviruses A Highly divergent an RNA with an RNA Polymerase dependent. Antiviral Res. 2019;169:104 541.

23. Holshue ML, DeBolt C, Lindquist S, et al. First case of 2019 novel coronavirus in the United States. N Engl J Med. 2020;382:929-936.

24. Chu CM, Cheng VCC, et al. Role of lopinavir/ ritonavir in the treatment of SARS: Initial virological and clinical findings. Thorax. 2004;59:252-256.

25. Delang L, Abdelnabi R, Neyts J. Favipiravir as a potential countermeasure against neglected and emerging RNA viruses. Antiviral Res. 2018;153:85-94.

26. Furuta Y, Komeno T, Nakamura T. Favipiravir (T-705), a broad spectrum inhibitor of viral RNA polymerase. Proc Jpn Acad, Ser B Phys Biol Sci. 2017;93:449-463.

27. Gao J, Tian Z, Yang X . Breakthrough: Chloroquine phosphate has shown apparent efficacy in treatment of COVID-19 associated pneumonia in clinical studies. Biosci Trends. 2020;14(1):72-73.

28. Mair-Jenkins J , Saavedra-Campos M, Baillie JK, et al .The effectiveness of convalescent plasma and hyperimmune immunoglobulin for the treatment of severe acute respiratory infections of viral etiology: a systematic review and exploratory meta-analysis. J Infect Dis. 2015,211(1):80-90. doi: 10.1093/infdis/jiu396

29. Chen L, Xiong J, Bao L, Shi Y. Convalescent plasma as a potential therapy for COVID-19.
Lancet Infect Dis. 2020;20(4):398-400. 